\title{
Role of B-Carotene Against Toxic Effect of Titanium Dioxide Nanoparticles on Cerebral Cortex of Adult Albino Rat: Histological and Biochemical Approach
}

Original
Article

\author{
Reham H. Abdel-kareem and Ayat M. Domouky
}

Human Anatomy and Embryology Department, Faculty of Medicine, Zagazig University, Egypt

\begin{abstract}
Objective: Detect the neurotoxic effect of titanium dioxide nanoparticles by investigation of the biochemical and histological changes in cerebral cortex of albino rats, and to evaluate the potential protective role of $\beta$-carotene against this toxicity. Methods: Titanium dioxide nanoparticles $\left(\mathrm{TiO}_{2} \mathrm{NPs}\right.$ ) administered intraperitoneal $100,300 \mathrm{mg} / \mathrm{kg}$, daily for 14 days besides one protected group received $10 \mathrm{mg} / \mathrm{kg} \beta$-carotene by gavage for 7 days prior and 14 days with $300 \mathrm{mg} / \mathrm{kg}$ nanoparticles administration, along with one control group and one group received $10 \mathrm{mg} / \mathrm{kg} \beta$-carotene by gavage for 21 days. Histological and histochemichal cerebral cortical tissue examination and standard biochemical methods for estimation of enzymes superoxide dismutase, glutathione peroxidase, catalase, alkaline phosphatase, gamma-glutamyl transpeptidase, and 5' nucleotidase were implemented.

Results: In contrast to administration of low dose $\mathrm{TiO}_{2} \mathrm{NPs}$, administration of high dose $\mathrm{TiO}_{2} \mathrm{NPs}_{\text {led }}$ to marked histological changes in form of decrease number of vesicular neurons and loss of background homogeneity with appearance of vacuolations and hydropic changes. Moreover, increase in astrocytes number with appearance of area of gliosis and increase in apoptosis index. Biochemical analysis showed significant decreases in the activities of the antioxidant enzymes: superoxide dismutase, glutathione peroxidase and catalase. Besides, significant decrease in the activities of alkaline phosphatase and gamma-glutamyl transpeptidase, although the activity of 5'-nucleotidase was not inclined significantly by administration of nanoparticles. These changes didn't markedly appear with the use of $\beta$-carotene.
\end{abstract}

Conclusion: High dose $\mathrm{TiO}_{2} \mathrm{NPs}$ has neurotoxic effects but application of $\beta$-carotene may serve as a beneficial medication to protect against neurotoxicity induced by nanoparticles.

Received: 29 August 2019, Accepted: 15 October 2019

Key Words: $\beta$-carotene, apoptosis, biochemical, neurotoxicity, titanium dioxide nanoparticles.

Corresponding Author: Ayat Mahmoud El-Domouky, M.D., Department Human Anatomy and Embryology, Faculty of Medicine, Zagazig University, Zagazig, Egypt, Tel.: +20 1012273554, E-mail: totabaty@yahoo.com, totabaty@gmail.com

ISSN: 1110-0559, Vol. 43, No.2

\section{INTRODUCTION}

Titanium dioxide nanoparticles $\left(\mathrm{TiO}_{2} \mathrm{NPs}\right)$ are one of the most broadly utilized engineered nanoparticles in the nanotechnology arena ${ }^{[1]}$. The yearly production of $\mathrm{TiO}_{2}$ NPs is increasing continuously; it is estimated to increase to 2.5 million metric tons annually by 2025 instead of 3,000 tons per year in $2002^{[2]}$. Titanium dioxide nanoparticles $\left(\mathrm{TiO}_{2} \mathrm{NPs}\right)$ have gained much significance due to their extensive use in nanodermatology and nanocosmetology ${ }^{[3]}$. $\mathrm{TiO}_{2}$ NPs are used in approximately $50 \%$ of sunscreen and cosmetics products ${ }^{[4]}$. Also, According to Coelho et al a there is a higher amount of $\mathrm{TiO}_{2} \mathrm{NPs}(<100 \mathrm{~nm})$ in candies, sweets and chewing gums, all can pass in human body through dermal, inhalation and oral routes of exposure ${ }^{[5]}$. The distinctive feature of $\mathrm{TiO}_{2}$ NPs is fast enter to the human body and then cause impending health hazards on human ${ }^{[6]}$. The adverse toxic effects of $\mathrm{TiO}_{2} \mathrm{NPs}$ have been studied in several animal models like rats, mice, rabbits and human ${ }^{[1,7,8]}$. The blood-brain barrier (BBB) can be crossed by nanoparticles so the central nervous system can show toxicity in the exposed animals ${ }^{[9,10]}$.
Studies have revealed numerous mechanisms by which these nanoparticles cause injuriousness, Exposure to $\mathrm{TiO}_{2}$ NPs considerably reduces the survival rate of neuron cells in a typical time and dose-dependent mode ${ }^{[11]}$. Oxidative stress is one of the most significant toxicity mechanisms in lung, kidney, brain and spleen ${ }^{[12,13]}$. Also, Gao et al. reported that oxidative stress-induced damage and inflammatory response in rat brain ${ }^{[14]}$. $\mathrm{TiO}_{2}$ NPs can induce an acute stress reaction in glial cells of mouse brains, leading to neuron damage and dysfunction $^{[15]}$. Moreover, Vasantharaja and Ramalingam reported that $\mathrm{TiO}_{2} \mathrm{NPs}$ cause direct interference with neuronal cell membranes enzymes such as alkaline phosphatase (ALP), 5' nucleotidase (5'-NT), and gamma-glutamyl transpeptidase $(\mathrm{GGT})^{[16]}$. Other in vivo studies informed that glial fibrillary acidic protein (GFAP) is an intermediate filament-III protein uniquely found in astrocytes in the CNS, non-myelinating Schwann cells in the PNS and enteric glial cells, GFAP gene activation and protein induction appear to play a critical role in astroglia cell activation (astrogliosis) following CNS injuries and neurodegeneration ${ }^{[17]}$. 
Carotenoids are naturally presented dyes and are responsible for the colors of some fruits and vegetables. $\beta$-carotene $(\beta C)$ has a wide range of biological and pharmacological effects including anti-epilepsy, radio-protective, and also, oxidant resistance ${ }^{[18,19]}$. Escalation of apoptotic index of testicular germ cells in $\mathrm{TiO}_{2} \mathrm{NPs}$ treated mice was prevented by $\beta \mathrm{C}^{[20]}$.

This study aimed to detect to the neurotoxic effect of $\mathrm{TiO}_{2}$ NPs by investigation of the pathological and biochemical changes in cerebral cortex after intraperitoneal injection of $\mathrm{TiO}_{2}$ NPs to albino rats, and to evaluate the potential protective role of $\beta$-carotene against this toxicity.

\section{MATERIALS AND METHODS}

\section{Animals}

50 healthy adult male albino rats (6-8weeks) weighing 150-200 g were used in this study. Rats were obtained from Animal House of the Faculty of Medicine, Zagazig University, Egypt. They were housed in a temperature- controlled and light-controlled room (12 h light/dark cycles) with free access to food and water.

All experimental animals were performed in accordance with relevant guidelines and regulations of the Institutional Animal Care and Use Committee, Zagazig university (ZU-IACUC committee), approval number ZU-IACUC/3/F/101/2019.

\section{Chemicals}

Nanopowder $<100 \mathrm{~nm}$ particles size was used, surface area of $35-65 \mathrm{~m} 2 / \mathrm{g}$ and purity $\geq 99.5 \%$ trace metals basis. It is white odorless fine powder mixture of rutile and anatase. Nanoparticles, $\beta$-carotene (in red orange powder form) and kits for enzymes assay were purchased from (Sigma-Aldrich chemical company, Germany and purchased from Sigma-Egypt).

Glial fibrillary acid protein (GFAP) antibodies were purchased from (AgilentDako, Copenhagen, Denmark). Caspase-3 antibodies were purchased from (Dako, Glostrup, Denmark).

Phosphate buffer (PBS), dissection set, $10 \%$ formal saline, alcohol, xylene and paraffin wax for preparation to light microscopic examination, and H\&E were available at faculty of medicine, Zagazig University

\section{Experiment Protocol}

50 adult male albino rats were divided into five groups each contain 10 rats: Control group contained 10 rats that were received intraperitoneal (i.p.) injection of $2 \mathrm{ml}$ saline, daily for 14 days. $\beta$-carotene $(\beta C)$ group contained 10 rats that were received $10 \mathrm{mg} / \mathrm{kg} \beta$-carotene once daily by gavage for 21 days $^{[21]}$. Low dose (LD) group contained 10 rats that were received intraperitoneal (i.p.) injection of $100 \mathrm{mg} / \mathrm{kg} \mathrm{TiO}$ NPs, daily for 14 days $^{[8]}$. High dose (HD) group contained 10 rats that were received intraperitoneal (i.p.) injection of $300 \mathrm{mg} / \mathrm{kg} \mathrm{TiO}, \mathrm{NPs}_{2}$, daily for 14 days $^{[22]}$. Protected group contained 10 rats that were received $10 \mathrm{mg} / \mathrm{kg} \beta$-carotene ${ }^{[21]}$ daily by gavage for 7 days prior and 14 days together with intraperitoneal (i.p.) injection of $300 \mathrm{mg} / \mathrm{kg} \mathrm{TiO}_{2} \mathrm{NPs}^{[22]}$. The extent of neurotoxicity was evaluated by biochemical and histological examination of cerebral cortical tissue samples from sacrificed rats.

\section{Histological Examination}

Cerebrum from each animal was carefully dissected and the specimens were immediately immersed in $10 \%$ formalin saline for $48 \mathrm{~h}$ to be processed to prepare 5 - $\mu \mathrm{m}$-thick paraffin sections and stained with hematoxylin and eosin (H\&E) to display the histological details according to Suvarna ${ }^{[18]}$.

\section{Immunohistochemical Study}

The immunohistochemical staining of anti-glial fibrillary acidic protein (GFAP) antibody was performed according to Neri et al. ${ }^{[23]}$. 4- $\mu$ m-thick paraffin sections mounted on slides covered with (3-aminopropyl) triethoxysilane. No pretreatment was necessary for antibody anti-GFAP. The dilution of primary antibody was: 1:300 ratio. The primary antibody was incubated for $120 \mathrm{~min}$ at $20^{\circ} \mathrm{C}$. The detection system utilized was the labeled streptavidin-biotin (LSAB + ) Kit (Agilent Dako, Copenhagen, Denmark), a refined avidin-biotin technique in which a biotinylated secondary antibody reacts with several peroxidase conjugated streptavidin molecules. In addition, double antigen labeling, using antibody anti GFAP, was performed. All sections were counter stained with Mayer's hematoxylin and examined by light microscopy. This immunohistochemical technique was carried out in the Department of histology, Faculty of Medicine, El-Monofia University.

The immunohistochemical staining of for caspase-3 was performed according to Bebars et al. ${ }^{[24]}$. 4- $\mu$ m-thick paraffin sections. The slides were incubated overnight at room temperature with a purified rabbit polyclonal antibody raised against caspase- 3 . It is received as $0.5 \mathrm{ml}$ concentrated for use. The Envision method was used for detection of antibody binding. The reaction was visualized by an appropriate substrate/chromogen (diaminobenzidine). All sections were counter stained with Mayer's hematoxylin and examined by light microscopy. This immunohistochemical technique was carried out in the Department of Histology, Faculty of Medicine, El-Monofia University.

\section{Interpretations of the Results}

Immunohistochemically, caspase-3 expression was confirmed by cytoplasmic and/or nuclear stain in examined cells. apoptotic index (the number of apoptotic (brown) cells present in a section expressed as a fraction of the total number of cells) was calculated in all examined sections.

Immunohistochemical staining of glial fibrillary acidic protein (GFAP) antibodies was conducted to examine the astrogliosis (over proliferation of astrocyte, glial cells). Darkness of astrocytes and thickness of their processes was calculated in all examined sections as area \% immunoreactivity. 


\section{Quantitative Morphometrical Measurements}

Sections stained with H\&E and immunohistochemically per $400 \times$ magnification were morphometrically analysed using Leica Qwin 500 Image Analyzer Computer System (England) at Anatomy Department, Faculty of Medicine, El-Monofia University. Quantitative data were collected for number of neurons with vesicular nuclei in $H \& E$ sections, the apoptotic (brown) cells present in a section expressed as a fraction of the total number of cells, the so-called apoptotic index, measures an apoptotic state (caspase-3 immunoreactivity) ${ }^{[25]}$. Area $\%$ anti-GFAP immunoreactivity in immunohistochemical stained sections $^{[23]}$. Quantitative data were estimated in 5 different non overlapped fields for the same slide of each animal, in each animal 5 slides were counted and a total number of 25 fields of each group were counted.

\section{Ex vivo Assay of Membrane Bounded Enzymes}

After completions of experiment rats were sacrificed, and whole intact brain was cautiously removed. Parts of cerebrums were cooled in ice-cold, $50 \mathrm{mmol}$ Tris- $\mathrm{HCl}$ buffer ( $\mathrm{pH} 7.55)$ and homogenized. The homogenate was centrifuged for $10 \mathrm{~min}$ at $3000 \mathrm{rpm}$, the supernatant was used for the assay of alkaline phosphatase (ALP), which plays a crucial role in the metabolism of the CNS, transmembrane transport mechanism, ion transport and maintenance of ionic strength. Also, 5' nucleotidase (5'-NT) which controls intracellular levels of nucleoside 5' monophosphates, and it is a major contributor to the cascade that completely hydrolyzes extracellular ATP to adenosine, furthermore gamma-glutamyl transpeptidase (GGT) which is chiefly concentrated in the vascular endothelium in the brain also mediates the cleaving of the dipeptidyl cysteinyl glycine, which provides cells with cysteine, a rate-limiting factor for the synthesis of $\mathrm{GSH}^{[16]}$.

Alkaline phosphatase (ALP): was performed according to Bessey et al. ${ }^{[26]}$. The ALP activity was calculated from the calibration curve obtained using paranitrophenol standard. ALP activity was expressed as units/mg protein, Gamma-glutamyl transpeptidase (GGT): was performed according to Orlowski and Meister ${ }^{[27]}$. GGT activity was expressed as units/mg protein, and $5^{\prime}$-nucleotidase (5'-NT): was performed according to Bergmeyer et al. ${ }^{[28]}$. 5'-NT activity expressed as units/mg protein.

\section{Ex vivo assay of Antioxidant Enzymes}

Other parts of cerebrums were separated instantly and homogenized in a phosphate buffer ( $\mathrm{pH} 7.6)$, centrifuged at $20,000 \mathrm{rpm}, 4{ }^{\circ} \mathrm{C}$ for $2 \mathrm{~h}$ to obtain a soluble salt part (SS). Re-extraction of the pellets was carried out to get a soluble detergent part (DS). The supernatant was collected and stored at $-20^{\circ} \mathrm{C}$. Protein concentrations were determined by the Bradford assay with Bovine serum albumin as standard $(0.05-1.00 \mathrm{mg} / \mathrm{ml})^{[29]}$.

\section{Catalase Assay (CAT)}

Was performed according to Chance and $\mathrm{AC}^{[30]}$. One unit of catalase activity was defined as an absorbance change of 0.01 as units/min, Superoxide dismutase assay (SOD): was performed according to Kakkar et al.$^{[31]}$. Results are expressed in units/mg protein, and Glutathione peroxidase assay (GPx): was performed according to Mohandas et al. ${ }^{[32]}$ Enzyme activity was calculated as nmol NADPH oxidized/ $\mathrm{min} / \mathrm{mg}$ protein using a molar extinction coefficient of $6.22 \times 103 \mathrm{M}-1 \mathrm{~cm}-1$.

\section{Statistical Analysis}

The data were collected from both biochemical results and morphometrical results, data were statistically analyzed using SPSS program (Statistical Package for Social Science) version 18.0. Quantitative data were expressed as mean \pm SD (Standard deviation). Paired sample T test and one-way ANOVA used to calculate differences between mean \pm SD of control group and mean \pm SD of each of the other three groups. Also, calculate differences between mean \pm SD of HD group and mean \pm SD of protected group. It's considered statistically significant when $p$ value $<0.05$, statistically highly significant when $p$ value $<0.001$ and non-significant when $p$ value $>0.05$.

\section{RESULTS}

\section{Histological Examination of Cerebral Tissue}

Cerebral cortical tissues stained with (H\&E) from Control group were present in their normal proportions and architectures, neurons cell bodies showed large vesicular nuclei and prominent nucleoli with more pyramidal cells in outer layer and more rounded cells in inner layer. Many cells surrounded by a clear rim. Also, there were few scattered small dark glial cells in a pink neuropil homogenous background. Meninges were normally attached to cerebral surface with no area of separations and no congested blood vessels (Figure 1a, b). In $\beta$-carotene $(\beta C)$ group, the pattern of histology in cortical tissue was similar to the control group (Figure 1c, d).

In low dose (LD) group: cerebral cortical tissues preserved its normal proportions and architectures, neurons cell bodies showed vesicular nuclei and few neurons showed dark stained nuclei, there was an infiltration with few small dark glial cells. Background and meninges kept their normal homogeneity (Figure 1e, f).

In high dose (HD) group: cerebral cortical tissues lost their normal proportions and architectures, neurons cell bodies showed dark stained nuclei with vacuolations around. Also, there was infiltration with many small dark glial cells as well as appearance of areas of gliosis. Background lost their normal homogeneity with appearance of vacuolations and hydropic changes. Meninges were separated from cerebral surface with congested blood vessels (Figure 1g, h)

In Protected group: cerebral cortical tissues preserved their normal proportions and architectures. There were many neurons with vesicular nuclei and prominent nucleoli and some neurons with dark stained nuclei. Also, there were few scattered small dark glial cells in pink neuropil homogenous 
background with less vacuolations and less hydropic changes. Meninges were normally attached to cerebral surface (Figure 1i, j).

\section{Immunohistochemical Examination of Cerebral Cortical Tissue}

The immunohistochemical staining for anti-GFAP showed increase in anti-GFAP immunopositivity in HD groups compared to other groups suggesting an upregulation of GFAP expression. GFAP staining darkened astrocytes which became visibly larger and more entangled with thickened processes; at $400 \mathrm{x}$ magnification (Figures 2a,b,c,d,e).

The immunohistochemical staining for anti-caspase-3 showed decrease in anti- caspase-3 immunopositivity in $\beta C$ groups compared to control group suggesting decrease in percentage of apoptotic active neurons, while, there was an increase in anti- caspase-3 immunopositivity in HD groups compared to other groups suggesting increase in percentage of apoptotic active neurons. With anti-caspase-3 staining, apoptotic active neurons became brown stained while healthy neurons stained blue with counter stain, at 400x magnification (Figures 3a,b,c,d,e).

\section{Quantitative Morphometrical Measurements and Statistical Analysis}

Number of neurons with vesicular nuclei (per 400 high power fields in H\&E stained slides of different studied groups) showed a high significant decreased in HD group and protected $\left(\mathrm{TiO}_{2} \mathrm{NPs}+\beta \mathrm{C}\right)$ groups compare to the control group $(P$ value $<0.001)$, and a high significant increase in protected group compare to the HD group $(P$ value $<0.001)$, it was clear that high dose $\mathrm{TiO}_{2} \mathrm{NPs}$ caused neuronal cell degeneration in the cerebral cortical tissue and $\beta \mathrm{C}$ might play a protective role (Figure 4a, Table 1).

Area \% of GFAP immunoreactivity (per 400 high power field in anti-GFAP immunohistochemical stained slides of different studied groups) showed a high significant increase in HD group and protected groups compare to the control group ( $P$ value $<0.001)$, a significant increase in LD group compare to the control group ( $P$ value $<0.05)$, and a high significant decrease in protected group compare to the HD group ( $P$ value $<0.001$ ), it was clear that high dose $\mathrm{TiO}_{2}$ NPs caused over proliferation of astrocytes, glial cells (astrogliosis) within cerebral cortex and $\beta C$ might play a protective role (Figure 4a, Table 1).

Percentage of apoptotic active neurons "apoptotic index" (per 400 high power fields in anti-caspase-3 immunohistochemical stained slides of different studied groups) showed that a high significant increase in HD group and protected groups compare to the control group ( $P$ value $<0.001)$, a significant decrease in $\beta \mathrm{C}$ group compare to the control group ( $P$ value $<0.05)$, and a high significant decrease in protected group compare to the HD group ( $P$ value $<0.001)$, it was clear that high dose $\mathrm{TiO}_{2}$ NPs caused increase apoptosis within cerebral cortex and $\beta C$ might play a protective role (Figure 4a, Table 1).

\section{Assay of Membrane Bound Enzymes and Statistical Analysis}

Measuring activities of membrane bound enzymes: ALP, 5'-NT and GGT in the cerebral tissues of different studied groups showed that high dose $\mathrm{TiO}_{2} \mathrm{NPs}$ caused significant decrease $(P$ value $<0.001)$ in the activity of ALP and GGT but no affection of 5 '-NT activity $(P$ value $>0.05)$ so it's obvious that high dose $\mathrm{TiO}_{2}$ NPs might affect CNS metabolism, trans-membrane transport mechanism, ion transport, maintenance of ionic strength and epithelial cell growth. Also $\beta \mathrm{C}$ might play a protective role as there was a high significant difference in protected group compare to the HD group $(P$ value $<0.001)$ (Figure $4 b$, Table 2$)$.

\section{.Assay of Antioxidant Enzymes and Statistical Analysis}

Measuring activities of the antioxidant enzymes CAT, GPx, and SOD in the cerebral tissues of different studied groups showed that administration of $\beta$-carotene led to high significant increase $(P$ value $<0.001,0.05)$ in antioxidant enzymes activities, in the other hand, administration high dose $\mathrm{TiO}_{2} \mathrm{NP}$ led to significant decrease $(P$ value $<0.001)$ in the activities of the antioxidant enzymes CAT, GPx, and SOD in the cerebral tissues. Moreover, there was a high significant increase in the enzymes activities in protected group compare to the HD group ( $P$ value $<0.001)$. These results suggest that high dose $\mathrm{TiO}_{2}$ NPs causes damage in the cerebral tissue after i.p. injection due to production of an oxidative stress and that it's why the anti-oxidative activities of $\beta C$ could prevent these pathological and biochemical damage to cerebrum (Figure 4c, Table 3 ). 


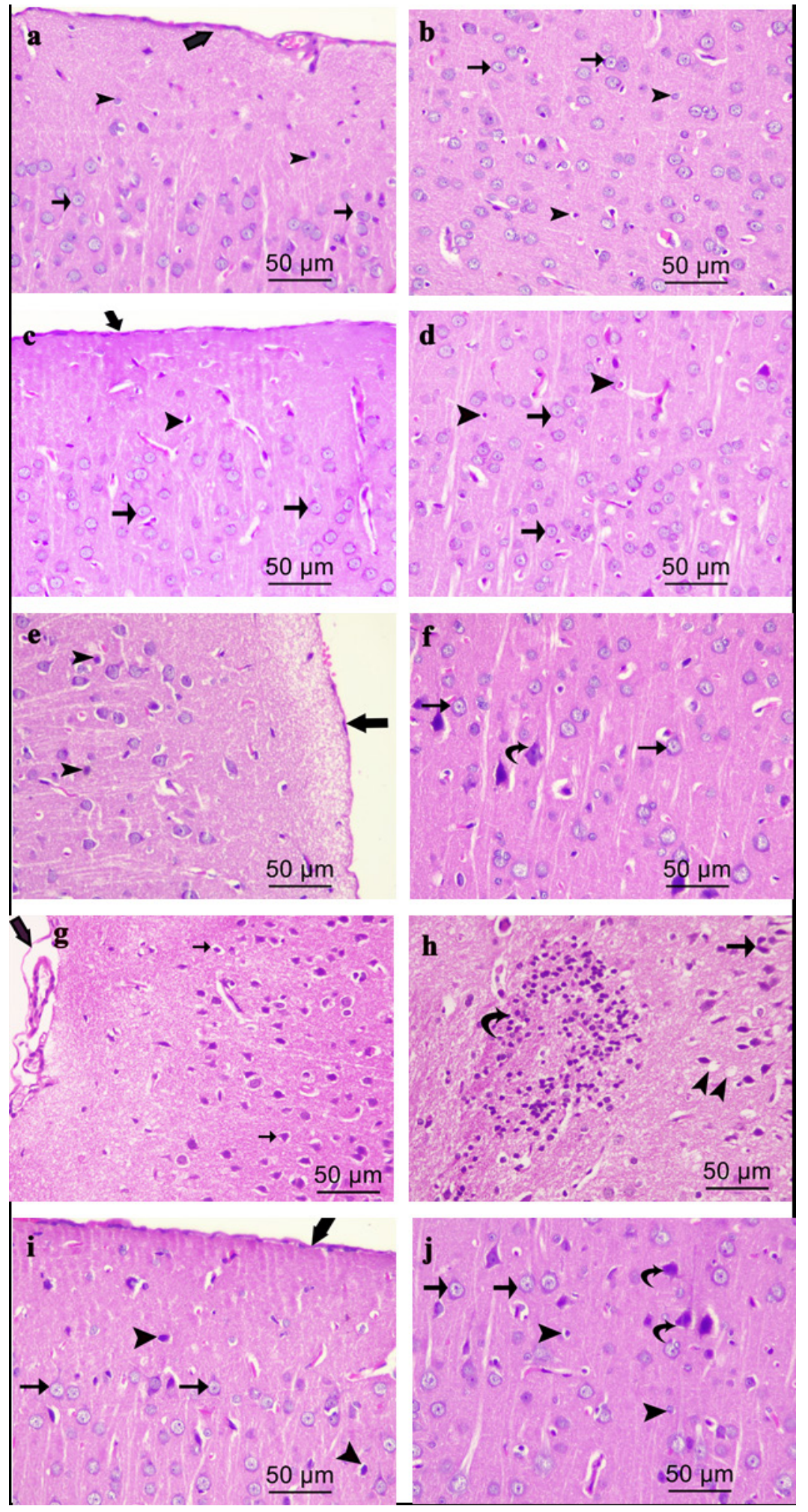

Fig. 1: H\&E stained cerebral cortical sections at 400x magnification. Control group $(a, b)$ and $\beta C$ group (c,d): showed large vesicular neurons nuclei with prominent nucleoli and clear rim around (arrows) and few scattered small dark glial cells (arrows heads) in a pink neuropil homogenous background. Meninges were normally attached to brain surface (thick arrow); (LD) group (e,f) showed many vesicular neurons nuclei (arrows), few neurons cell bodies with dark stained nuclei (curved arrow), few infiltration with small dark glial cells (arrows heads), meninges kept their normal homogeneity (thick arrow); HD group (g, h) showed many dark stained neurons nuclei with vacuolations around (arrows) and over proliferation with small dark glial cells with area of gliosis (curved arrow), background lost their normal homogeneity with appearance vacuolations and hydropic changes (arrows heads), meninges were separated from brain surface with congested blood vessels (thick arrow); Protected group (i,j) showed vesicular neurons nuclei with prominent nucleoli (arrows) but some neurons cell bodies had dark stained nuclei (curved arrow), few scattered small dark glial cells (arrows heads), in a pink neuropil background with less hydropic changes. Meninges were normal attached to brain surface (thick arrow). 


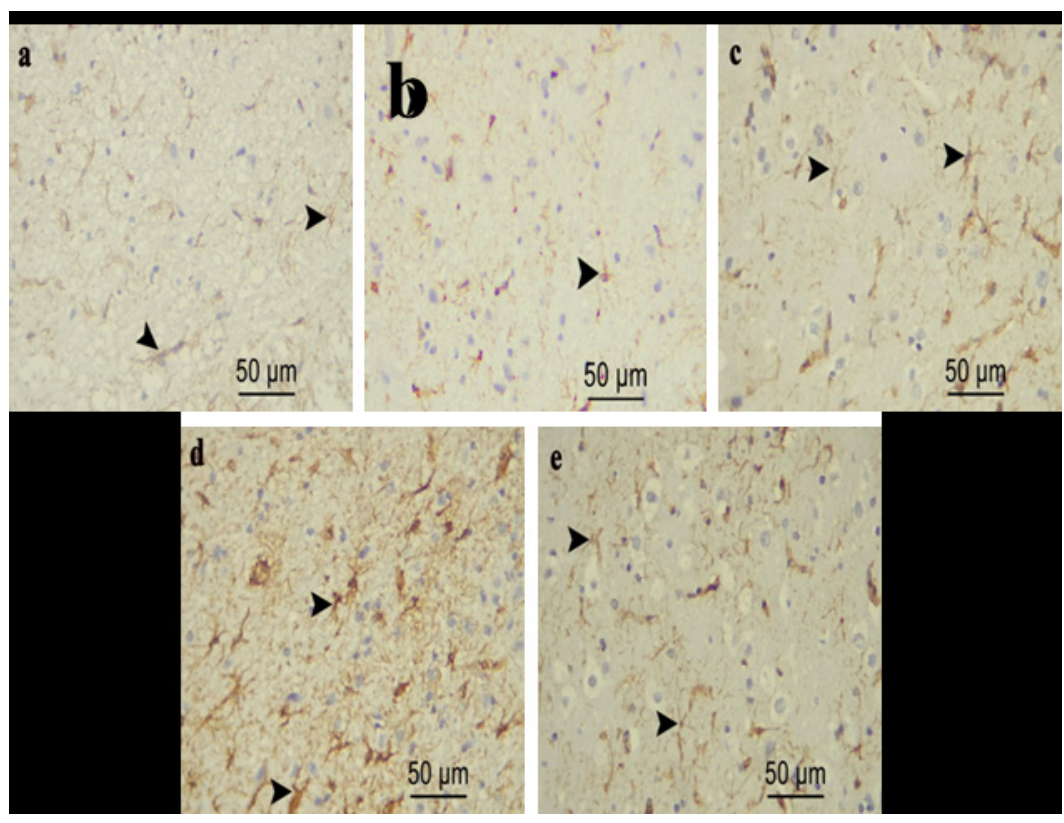

Fig. 2: Immunohistochemical staining for anti-GFAP, (a: control group; b: $\beta C$ group; $c$ : LD group; d: HD group; e: protected group) arrows heads referred to stained astrocyte; in HD group: astrocytes were dark with thick processes.

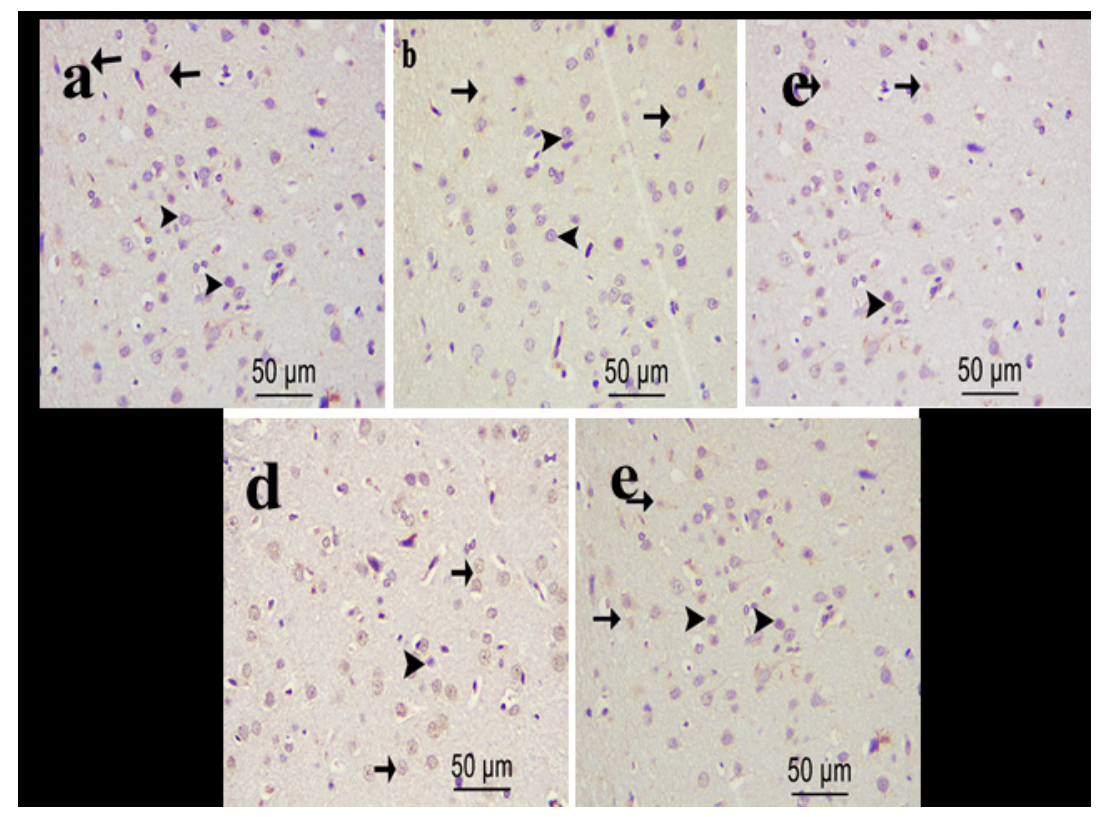

Fig. 3: Immunohistochemical staining for anti-caspase-3, (a: control group; b: $\beta C$ group; c: LD group; d: HD group; e: protected group) arrows heads: neurons nuclei stained blue with counter stain (no apoptosis), arrows: brown stained neurons nuclei with anti-caspase-3 (active apoptosis), which is mainly increased in HD group. 

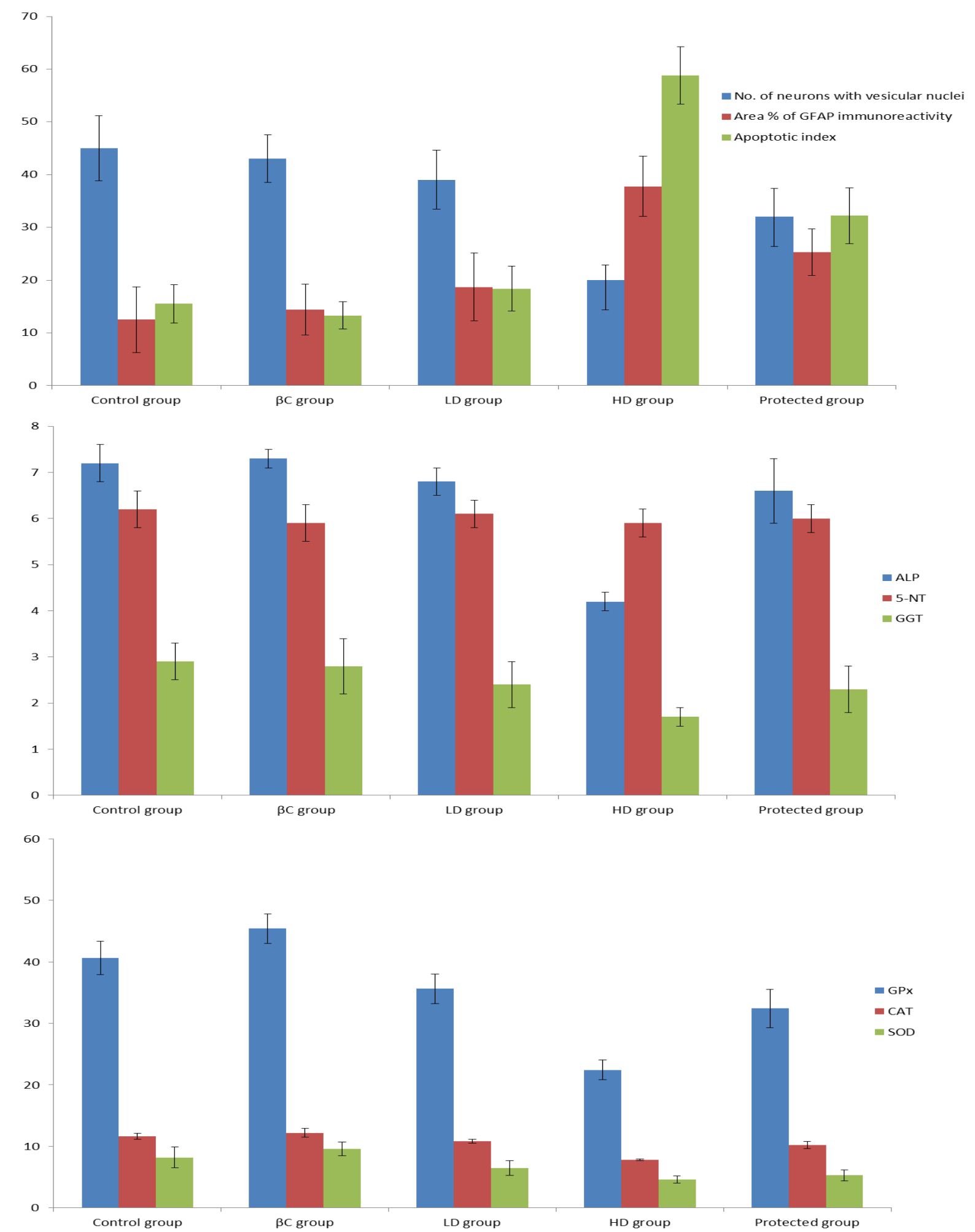

Fig. 4: morphometric and stastical biochemical analysis: a: Mean \pm standard deviation (SD) of morphometric measures for studied groups; b: Mean \pm standard deviation (SD) of neuronal cell membranes enzymes ALP, 5'-NT, and GGT in the cerebral tissues for studied groups; c: Mean \pm standard deviation (SD) of the antioxidant enzymes CAT, GPx, and SOD in the cerebral tissues for studied groups 
Table 1: Mean \pm SD of number of neurons with vesicular nuclei, Area \% of GFAP immunoreactivity, and apoptotic index (caspase-3 immunoreactivity) per 400 high power fields, with stastical difference between control group and each of other groups.

\begin{tabular}{|c|c|c|c|c|c|}
\hline & Control group & $\beta C$ group & LD group & HD group & Protected group \\
\hline No. of neurons with vesicular nuclei & $45 \pm 6.2$ & $43 \pm 4.5$ & $39 \pm 5.6$ & $20 \pm 2.9^{* *}$ & $32 \pm 5.4^{* * \# \#}$ \\
\hline Area $\%$ of GFAP immunoreactivity & $12.5 \pm 6.2$ & $14.4 \pm 4.8$ & $18.7 \pm 6.4^{*}$ & $37.8 \pm 5.7^{* *}$ & $25.3 \pm 4.4^{* * \#}$ \\
\hline Apoptotic index & $15.5 \pm 3.6$ & $13.3 \pm 2.6^{*}$ & $18.4 \pm 4.3$ & $58.8 \pm 5.4^{* *}$ & $32.2 \pm 5.3^{* * \#}$ \\
\hline
\end{tabular}

* Significant $P<0.05$ Vs control group

**Highly significant $P<0.001$ Vs control group

\# Significant $P<0.05$ Vs HD group

\#\# Highly significant $P<0.001 \mathrm{Vs}$ HD group

Table 2: Mean \pm SD of membrane bound enzymes ALP, 5'-NT, and GGT of different studied groups, with stastical difference between control group and each of other groups.

\begin{tabular}{|c|c|c|c|c|c|}
\hline & Control group & $\beta C$ group & LD group & HD group & Protected group \\
\hline Alkaline phosphatase (U/mg protein) & $7.2 \pm 0.4$ & $7.3 \pm 0.2$ & $6.8 \pm 0.3^{*}$ & $4.2 \pm 0.2^{* *}$ & $6.6 \pm 0.7^{* \#}$ \\
\hline 5'-nucleotidase (U/mg protein) & $6.2 \pm 0.4$ & $5.9 \pm 0.4$ & $6.1 \pm 0.3$ & $5.9 \pm 0.3$ & $6 \pm 0.2$ \\
\hline Gamma-glutamyl transpeptidase (U/mg protein) & $2.9 \pm 0.4$ & $2.8 \pm 0.6$ & $2.4 \pm 0.5^{*}$ & $1.7 \pm 0.2^{* *}$ & $2.3 \pm 0.5^{* \#}$ \\
\hline
\end{tabular}

*Significant $P<0.05$ Vs control group

**Highly significant $P<0.001$ Vs control group

\# Significant $P<0.05 \mathrm{Vs}$ HD group

\#\# Highly significant $P<0.001$ Vs HD group

Table 3: Mean \pm SD of antioxidant enzymes GPx, CAT, and SOD of different studied groups, with stastical difference between control group and each of other groups.

\begin{tabular}{|c|c|c|c|c|c|}
\hline & Control group & $\beta C$ group & LD group & HD group & Protected group \\
\hline Glutathione peroxidase (GPx) (nmol/mg protein) & $40.6 \pm 2.7$ & $45.4 \pm 2.4^{* *}$ & $35.6 \pm 2.4^{*}$ & $22.4 \pm 1.6^{* *}$ & $32.4 \pm 3.1^{* * \#}$ \\
\hline Catalase (CAT) (U/min.) & $11.6 \pm 0.5$ & $12.2 \pm 0.7^{*}$ & $10.8 \pm 0.3^{*}$ & $7.8 \pm 0.1^{* *}$ & $10.2 \pm 0.6^{* * \#}$ \\
\hline Superoxide dismutase (SOD) (U/mg protein) & $8.2 \pm 1.7$ & $9.6 \pm 1.1^{*}$ & $6.5 \pm 1.2^{*}$ & $4.6 \pm 0.6^{* *}$ & $5.3 \pm 0.9^{* * \#}$ \\
\hline
\end{tabular}

*Significant $P<0.05$ Vs control group

**Highly significant $P<0.001 \mathrm{Vs}$ control group

\# Significant $P<0.05 \mathrm{Vs}$ HD group

\#\# Highly significant $P<0.001 \mathrm{Vs}$ HD group

\section{DISCUSSION}

Among high-demand commercial NPs, Titanium dioxide nanoparticles $\left(\mathrm{TiO}_{2} \mathrm{NPs}\right)$ have been widely used as a white pigment, personal skincare product, water-treatment agent, and bactericidal agent owing to their high stability and anticorrosive and photocatalytic properties ${ }^{[33]} \cdot \mathrm{TiO}_{2} \mathrm{NPs}$ are one of the most widely used nanomaterials in the consumer products, agriculture, and energy sectors, their large demand and widespread applications will inevitably cause damage to organisms and ecosystems ${ }^{[34]}$. A better understanding of $\mathrm{TiO}_{2}$ NPs toxicity in humans may promote risk assessment and safe use applies of these nanomaterials ${ }^{[35]}$. This is the cause we shed light on the neurotoxic effect of $\mathrm{TiO}_{2}$ NPs by using two different doses: low dose $(100 \mathrm{mg} / \mathrm{kg})$ (LD group) and high doses (300 mg/kg) (HD group). Moreover, this study differs from others as it evaluated the potential protective role of $\beta$-carotene against this neurotoxicity, as it has been well revealed that oxidative stress plays a critical role in the mechanism of NPs toxicity ${ }^{[36]}$. $\beta C$ possesses a wide array of pharmacological and biological activities including: antioxidant, radio-protective, cardiovascular protection, anti-epilepsy ${ }^{[19]}$.
In our study, we concluded that with administration of low dose $\mathrm{TiO}_{2}$ NPs $(100 \mathrm{mg} / \mathrm{kg})$, there were no marked histological changes, while these changes appeared with high dose $\mathrm{TiO}_{2}$ NPs $(300 \mathrm{mg} / \mathrm{kg}$ ). Also, biochemical changes in LD group were much less than HD group. So, it is obvious that a pathological and biochemical changes occurred in a dose dependent manner. This result approved with Liu et al. who noticed dose-dependent alteration in pro-inflammatory markers (TNF- $\alpha$, IL-1 $\beta$ and IL-10) ${ }^{[37]}$ and with Xu et al. ${ }^{[38]}$ and $\mathrm{Jia}$ et $a l .{ }^{[8]}$ who mentioned that histopathological examination of cerebral tissues after administration of high doses $\mathrm{TiO}_{2}$ NPs revealed that there were pathological lesions in a dose dependent manner. Moreover, Gandamalla et al. said NPs were induced greater cytotoxicity in the colon, liver, lung and skin cells at higher concentrations 100 and 300 $\mu \mathrm{g} / \mathrm{ml}$ significantly ${ }^{[1]}$. But on other hand Federici et al. made his study on fish, said the effect was not dose dependent ${ }^{[39]}$. Also, our results not in agreement with Vasantharaja and Ramalingam who said that on $100 \mathrm{mg} / \mathrm{kg} \mathrm{TiO} 2$ NPs treated groups, the brain tissues had abnormal pathological changes in form of proliferation of ependyma and spongiocyte, also they reported marked biochemical changes with administration of $100 \mathrm{mg} / \mathrm{kg} \mathrm{TiO}{ }_{2} \mathrm{NPs}^{[16]}$. 
On histological examination of cerebral tissue of high dose $\mathrm{TiO}_{2}$ NPs group, cerebral cortical tissues lost their normal proportions and architectures, neurons cell bodies showed dark stained nuclei with vacuolations around. Also, there was infiltration with small dark glial cells with area of gliosis. Background lost their normal homogeneity with appearance of vacuolations and hydropic changes. Meninges were separated from cerebral surface with congested blood vessels. These results also established by Wang et al. who demonstrated an irregular arrangement and loss of neurons after $\mathrm{TiO}_{2} \mathrm{NPs}$ administration ${ }^{[40]}$. And with $\mathrm{Xu}$ et al. who approved different degrees of damage in the brain and lung, the brain tissue showed neuronal cell degeneration and vacuoles ${ }^{[38]}$. Moreover, in an in vivo study by $\mathrm{Li}$ et al. ${ }^{[41]}$, mice were chronically exposed to $\mathrm{TiO}_{2} \mathrm{NPs}$ of via intratracheal instillations, after 4 weeks, inflammatory cell aggregation and neuron necrosis were present. Study passed by Jia et al. showed that treatment of mice with $150 \mathrm{mg} / \mathrm{kg}$ of $\mathrm{TiO}_{2} \mathrm{NPs}$ resulted in invasion of inflammatory cells in the brain tissue and morphological damage to brain tissue ${ }^{[8]}$. On other hand our results weren't in agreement with Aijie et al. who examined the pathological changes of the brain using hematoxylin-eosin staining and mentioned that the

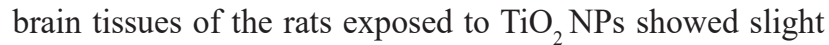
injuries and there were no obvious pathological changes in the brain ${ }^{[42]}$. this difference may be due to the way of administration in our study, we used intraperitoneal route but Aijie et al. ${ }^{[42]}$ used taste pathway, but our results compatible with Aijie et al. in other chemical findings. Another conflict with Chen et al. who revealed that histological examination of brain showed lack of any significant histological alteration, vacuolation, oedema and cellular atrophy after a long time exposure $\mathrm{TiO}_{2}$ NPs in the brain of zebrafish ${ }^{[43]}$.

Quantitative morphometrical analysis for H\&E stained section proved that high dose $\mathrm{TiO}_{2}$ NPs caused neuronal cell degeneration in the brain tissue. This result agreed with Wang et al. who cleared that an irregular appearance of neurons and a drastic neuronal loss, in parallel with increased number of activated astrocytes occurred after nasal instillation of $\mathrm{TiO}_{2} \mathrm{NPs}^{[44]}$. Also our result proved with studies investigated that $\mathrm{TiO}_{2} \mathrm{NPs}$ in the brain can also lead to neurodegeneration ${ }^{[42,45,46]}$.

Astrocytes are one type of glial cells in the CNS, a group that also includes resident and perivascular microglia, oligodendrocytes, radial glia and Muller cells. In fact, it is estimated that astroglia cells are the most abundant cell types in the brain, providing both structural and functional support for neurons. Astrocytes (astroglia) are characterized by the presence of a unique structural protein, glial fibrillary acidic protein (GFAP) ${ }^{[17]}$. Furthermore, Eng et al. and Shun-Fen et al. mentioned that with neuroinflammation, brain injury cause activation and proliferation of astroglia cells "reactive astrogliosis" into damaged areas and a concomitant increase in GFAP levels ${ }^{[47,48]}$. According to these facts, we evaluated neurotoxic effect of $\mathrm{TiO}_{2}$ NPs by immunohistochemical staining of glial fibrillary acidic protein (GFAP) antibodies to examine the astrogliosis in the cerebrum. Our study showed that there was up-regulation of GFAP expression in HD group more than LD group. Anti-GFAP staining darkened astrocytes which became visibly larger more entangled with thickened processes this prove infiltration of cerebral tissue with a strocytes, glial cells (astrogliosis). These results cope with Aijie et al. who proved that with administration $\mathrm{TiO}_{2}$ NPs, the number of astrocytes (brown) significantly increased in the cerebral cortex, so they concluded that NPs that translocated into brain tissues suppressed cell proliferation, caused DNA damage and increased astrocytes ${ }^{[2]}$. As well, over proliferation of glial cells was observed by ${ }^{[49]}$. Upregulation of persistent brain inflammation markers such as IL-1 $\beta$, IP-10 and GFAP were noticed by ${ }^{[50,51]}$.

Release of cytochrome c from the internal part of the mitochondrial membrane into the cytosol results in the activation of caspase cascades, in particular caspase- $9,-3,-6$, and -7 , caspase- 3 is the main executioner of apoptosis ${ }^{[52,53]}$. So in our study, immunohistochemical staining of caspase-3 antibodies was conducted to understand the way of this neuronal damage. Anti-caspases-3 selectively stained the neurons cell bodies that consistent with apoptosis, there were decrease in apoptotic index in $\beta C$ group and up-regulation of apoptosis-related proteins and increase in percentage of apoptotic active neurons in HD group. These results reached also by Xu et al., who established that NPs are more likely to induce cell damage, lead to apoptosis ${ }^{[38]}$. Apoptosis after $\mathrm{TiO}_{2}$ NPs administration was also approved by different ways in studies done by ${ }^{[8,34,54,55]}$.

Comparing the activities of membrane bound enzymes: ALP, 5'-NT and GGT in the brain tissues of different studied groups showed that high dose $\mathrm{TiO}_{2}$ NPs caused decrease in the activity of ALP and GGT but no affection of 5'-NT activity. So it's obvious that high dose $\mathrm{TiO}_{2} \mathrm{NPs}$ might affect CNS metabolism, trans-membrane transport mechanism, ion transport, maintenance of ionic strength and epithelial cell growth. These results evidently indicate that $\mathrm{TiO}_{2} \mathrm{NPs}$ could impair the membrane stability in brain cerebral cortex. Vasantharaja and Ramalingam reported same results but with low dose $\mathrm{TiO}_{2}$ NPs as previously mentioned, they said " $\mathrm{TiO}_{2}$ NPs could impair the electrochemical gradient, ionic homeostasis and membrane stability in different regions of the rat brain as the enzymes ATPases, ALP, 5'-NT and GGT activities were significantly decreased in $\mathrm{TiO}_{2} \mathrm{NPs}$ treated groups maximally in the cerebral hemisphere" ${ }^{216]}$.

Comparing the activities of the antioxidant enzymes SOD, GPx, and CAT in the brain tissues of different studied groups showed that administration high dose $\mathrm{TiO}_{2} \mathrm{NPs}$ led to significant decrease in the activities of the antioxidant enzymes SOD, GPx, and CAT more than low dose NPs in cerebral cortex. These results suggest that high dose $\mathrm{TiO}_{2}$ NPs causes damage in the brain after i.p. injection due to production of an oxidative stress. These results were in agreement with $^{[34,54,55]}$ who stated that oxidative stress induced by ROS are considered key factors in intracellular $\mathrm{TiO}_{2}$ NP-induced organ injury. Also, Rajakumar et al. proved same results in hepatotoxicity induced by $\mathrm{TiO}_{2} \mathrm{NPs}^{[56]}$. Additionally, the levels of superoxide dismutase (SOD), 
glutathione peroxidase were significantly decreased in rats exposed to $\mathrm{TiO}_{2} \mathrm{NPs}$ as mentioned by ${ }^{[42]}$. Activity of SOD and Catalase reduced significantly following exposure to NPs in mouse erythrocytes as declared by ${ }^{[57]}$. A dramatic increase of the ROS levels, accompanied by the decreased levels of activity/concentration of ROS scavengers (SOD, CAT, GPx, and ascorbic acid) was observed in the hippocampus of orally exposed mice ${ }^{[58]}$. Higher doses of $\mathrm{TiO}_{2} \mathrm{NPs}$ increased $\mathrm{O} 2-\mathrm{H} 2 \mathrm{O} 2$, and MDA levels, decreased the activities of the antioxidant enzymes CAT, GPx, and $\mathrm{SOD}^{[8]}$. In opposing, a transient, short term increase of the activity/concentration of the major antioxidants (GPx, SOD) was observed after intranasal administration of $\mathrm{TiO}_{2} \mathrm{NPs}$, but it normalized at the end of experiment (30 days $)^{[40]}$. However, Wang et al., mentioned that the activity of CAT increased, whereas SOD activity decreased in exposure to $\mathrm{TiO}_{2} \mathrm{NPs}^{[40]}$.

It is well known that $\beta$-carotene has an antioxidant effect ${ }^{[19,20,21,59]}$. Moreover, Orazizadeh et al. demonstrated that $\beta \mathrm{C}$ improved the spermatogenesis defects in $\mathrm{TiO}_{2} \mathrm{NPs}$ treated mice ${ }^{[60]}$. It has also been reported that $\beta \mathrm{C}$ decreases oxidative stress and prevents ethanol-induced cell death by inhibiting caspase- 9 and caspase- 3 expression ${ }^{[61]}$. Therefore in our study, administration of $\beta \mathrm{C}$ alone led to increase in antioxidant enzymes activities as noticed in studies carried by $^{[62,63]}$. Also, in our results $\beta C$ used to prevent neurotoxic effect of $\mathrm{TiO}_{2}$ NPs. $\beta \mathrm{C}$ was given in a dose of $10 \mathrm{mg} / \mathrm{kg}$ by gavage 7 days prior and 14 days with high dose $\mathrm{TiO}_{2}$ NPs administration (protected group). According to histological and pathological finding, we concluded that $\beta C$ may protect against oxidative stress so it can prevent pathological and biochemical changes expected by high dose $\mathrm{TiO}_{2} \mathrm{NPs}$. In other studies $\mathrm{N}$-acetylcystiene played a protective effect against titanium dioxide nanoparticles oxidative stress in immune cells ${ }^{[64]}$ and in keratinocyte ${ }^{[65]}$.

\section{CONCLUSION}

In summary, $\mathrm{TiO}_{2} \mathrm{NPs}$ cause neurotoxic effect in a dose dependent manner. Administration of high dose $\mathrm{TiO}_{2} \mathrm{NPs}$ (300 mg/kg i.p. for 14 days) caused pathological neuronal degeneration with apoptosis and astrogliosis and biochemical changes in form of decrease activity of membrane bound enzymes: ALP, 5'-NT and GGT, besides the decrease in activity of antioxidant enzyme (CAT, GPx, and SOD). These results suggested that high dose $\mathrm{TiO}_{2}$ NPs caused damage in the cerebrum due to production of an oxidative stress. This stress successfully prevented by $\beta C$. Administration of $10 \mathrm{mg} / \mathrm{kg} \beta C$ by gavage 7 days prior and 14 days with high dose $\mathrm{TiO}_{2}$ NPs could prevent the pathological and biochemical changes in protected group.

\section{ABBREVIATION}

5'-NT: 5'-nucleotidase; ALP: alkaline phosphatase; BBB: blood-brain barrier; $\mathbf{\beta C}$ : Beta-carotene; CAT: Catalase; GFAP: glial fibrillary acid protein; GGT: gammaglutamyl transpeptidase; GPx: glutathione peroxidase; i.p.: intraperitoneal injection; ROS: reactive oxygen species; SOD: superoxide dismutase; TiO ${ }_{2}$ NPs: Titanium dioxide nanoparticles.

\section{AUTHOR CONTRIBUTIONS STATEMENT}

R.H prepared animals and chemicals, carried out histologicals and chemical analysis. revised maunscrip. A.D wrote the main manuscript text, calculated statistics and revised figures. All authors reviewed the manuscript (no conflict of interest).

\section{ACKNOWLEDGEMENTS}

Special thanks to Anatomy Department, Faculty of Medicine, Zagazig University. Many thanks to Zagazig University Animal House Department and Scientific Medical Research Center.

\section{CONFLICTS OF INTEREST}

There are no conflicts of interest

\section{REFERENCES}

1. Gandamalla D, Lingabathula H, Yellu NR. Cytotoxicity evaluation of titanium and zinc oxide nanoparticles on human cell lines. Int J Pharmcy Pharm Sci International Journal of Pharmacy and Pharmaceutical Sciences. 2017;9(11):240-6.

2. Robichaud CO, Uyar AE, Darby MR, Zucker LG, Wiesner MR. Estimates of Upper Bounds and Trends in Nano- $-\mathrm{TiO}_{2} \sim$ Production As a Basis for Exposure Assessment. ENVIRONMENTAL SCIENCE AND TECHNOLOGY -WASHINGTON DC-. 2009;43(12):4227-33.

3. Ammendolia MG, Iosi F, Maranghi F, Tassinari R, Cubadda F, Aureli F, et al. Short-term oral exposure to low doses of nano-sized $\mathrm{TiO}_{2}$ and potential modulatory effects on intestinal cells. FCT Food and Chemical Toxicology. 2017;102:63-75.

4. Hu R, Gong X, Duan Y, Li N, Che Y, Cui Y, et al. Neurotoxicological effects and the impairment of spatial recognition memory in mice caused by exposure to $\mathrm{TiO}_{2}$ nanoparticles. Biomaterials Biomaterials. 2010;31(31):8043-50.

5. Coelho SG, Patri AK, McNeil SE, Wokovich AM, Howard PC, Miller SA. Repetitive application of sunscreen containing titanium dioxide nanoparticles on human skin. JAMA Dermatol JAMA Dermatology. 2016;152(4):470-2.

6. Warheit DB, Hoke RA, Finlay C, Donner EM, Reed KL, Sayes CM. Development of a base set of toxicity tests using ultrafine $\mathrm{TiO}_{2}$ particles as a component of nanoparticle risk management. Toxicology letters. 2007;171(3):99-110.

7. Grassian VH, O'Shaughnessy P T, AdamcakovaDodd A, Pettibone JM, Thorne PS. Inhalation exposure study of titanium dioxide nanoparticles with a primary particle size of 2 to $5 \mathrm{~nm}$. Environ Health Perspect. 2007;115(3):397-402. 
8. Jia X, Wang S, Zhou L, Sun L. The Potential Liver, Brain, and Embryo Toxicity of Titanium Dioxide Nanoparticles on Mice. Nanoscale Res Lett Nanoscale Research Letters. 2017;12(1):1-14.

9. Lockman PR, Koziara JM, Mumper RJ, Allen DD. Nanoparticle surface charges alter blood-brain barrier integrity and permeability. Journal of drug targeting. 2004;12(9-10):9-10.

10. Chen HW, Su SF, Chien CT, Lin WH, Yu SL, Chou $\mathrm{CC}$, et al. Titanium dioxide nanoparticles induce emphysema-like lung injury in mice. FASEB journal : official publication of the Federation of American Societies for Experimental Biology. 2006;20(13):2393-5.

11. Wu J, Sun J, Xue Y. Involvement of JNK and P53 activation in $\mathrm{G} 2 / \mathrm{M}$ cell cycle arrest and apoptosis induced by titanium dioxide nanoparticles in neuron cells. Toxicol Lett Toxicology Letters. 2010;199(3):269-76.

12. Li N, Duan Y, Hong M, Zheng L, Fei M, Zhao $\mathrm{X}$, et al. Spleen injury and apoptotic pathway in mice caused by titanium dioxide nanoparticules. Toxicology Letters Toxicology Letters. 2010; 195(2-3):161-8.

13. Sang X, Zheng L, Sun Q, Li N, Cui Y, Hu R, et al. The chronic spleen injury of mice following long-term exposure to titanium dioxide nanoparticles. JBM Journal of Biomedical Materials Research Part A. 2012;100A(4):894-902.

14. Gao X, Yin S, Tang M, Chen J, Yang Z, Zhang $\mathrm{W}$, et al. Effects of Developmental Exposure to $\mathrm{TiO}<\mathrm{sub}>2</$ sub $>$ Nanoparticles on Synaptic Plasticity in Hippocampal Dentate Gyrus Area: an In Vivo Study in Anesthetized Rats. Biological Trace Element Research. 2011;143(3):1616-28.

15. Pogue AI, Jones BM, Bhattacharjee S, Lukiw WJ, Percy ME, Zhao Y. Metal-sulfate induced generation of ROS in human brain cells: Detection using an isomeric mixture of 5- and 6-carboxy-2,7dichlorofluorescein diacetate (carboxy-DCFDA) as a cell permeant tracer. Int J Mol Sci International Journal of Molecular Sciences. 2012;13(8):9615-26.

16. Vasantharaja D, Ramalingam V. NEUROTOXIC EFFECT OF TITANIUM DIOXIDE NANOPARTICLES: BIOCHEMICAL AND PATHOLOGICAL APPROACH IN MALE WISTAR RATS. Int J App Pharm International Journal of Applied Pharmaceutics. 2018;10(4):74.

17. Yang Z, Wang KKW. Glial fibrillary acidic protein: from intermediate filament assembly and gliosis to neurobiomarker. Trends in Neurosciences Trends in Neurosciences. 2015;38(6):364-74.
18. Suvarna SK. Bancroft's theory and practice of histological techniques consult. (Erscheinungsort nicht ermittelbar): Churchill Livingstone, Elsevier; 2013. 173-87 p.

19. Schweiggert RM, Kopec RE, Villalobos-Gutierrez MG, Högel J, Quesada S, Esquivel $\mathrm{P}$, et al. Carotenoids are more bioavailable from papaya than from tomato and carrot in humans: a randomised cross-over study. Br J Nutr British Journal of Nutrition. 2014;111(03):490-8.

20. Orazizadeh M, Daneshi E, Hashemitmar M, Absalan F, Khorsandi L. Protective effect of beta-carotene against titanium dioxide nanoparticles induced apoptosis in mouse testicular tissue. Andrologia. 2015;47(7):816-25.

21. Iyama T, Takasuga A, Azuma M. beta-Carotene accumulation in mouse tissues and a protective role against lipid peroxidation. International journal for vitamin and nutrition research Internationale Zeitschrift fur Vitamin- und Ernahrungsforschung Journal international de vitaminologie et de nutrition. 1996;66(4):301-5.

22. Jiaying X, Hongbo S, Magaye R, Hongsheng Y, Lissy $\mathrm{L}$, Baobo Z, et al. Acute Toxicity of Intravenously Administered Titanium Dioxide Nanoparticles in Mice. PLOS ONE. 2013;8.

23. Neri M, Frati A, Turillazzi E, Cantatore S, Cipolloni $\mathrm{L}$, Di Paolo $\mathrm{M}$, et al. Immunohistochemical Evaluation of Aquaporin-4 and its Correlation with CD68, IBA-1, HIF-1a, GFAP, and CD15 Expressions in Fatal Traumatic Brain Injury. IJMS International Journal of Molecular Sciences. 2018;19(11):3544.

24. Bebars SMM, Al-Sharaky DR, Gaber MA, Afify DR. Immunohistochemical Expression of Caspase-3 in Psoriasis. Journal of clinical and diagnostic research : JCDR. 2017;11(7):01.

25. Bressenot A, Marchal S, Bezdetnaya L, Garrier J, Guillemin F, Plenat F. Assessment of apoptosis by immunohistochemistry to active caspase-3, active caspase-7, or cleaved PARP in monolayer cells and spheroid and subcutaneous xenografts of human carcinoma. J Histochem Cytochem. 2009; 57(4): 289-300.

26. Bessey OA, Lowry OH, Brock MJ. A method for the rapid determination of alkaline phosphates with five cubic millimeters of serum. The Journal of biological chemistry. 1946;164:321-9.

27. Orlowski M, Meister A. ISOLATION OF GAMMA-GLUTAMYL TRANSPEPTIDASE FROM HOG KIDNEY. The Journal of biological chemistry. 1965;240:338-47. 
28. Bergmeyer HU, Gawehn K, Williamson DH. Methods of enzymatic analysis. Volume 2 Volume 2. Weinheim; New-York; Londres: Verlag chemie; Academic Press; 1974. 5 p.

29. Khan RA, Khan MR, Sahreen S. Brain antioxidant markers, cognitive performance and acetylcholinesterase activity of rats: efficiency of Sonchus asper. Behav Brain Funct. 2012;8:21.

30. Chance B, AC M. Assay of catalase and peroxidases. Met Enzymol. 1955;11:764-75.

31. Kakkar P, Das B, Viswanathan PN. A modified spectrophotometric assay of superoxide dismutase. Indian journal of biochemistry \& biophysics. 1984;21(2):130-2.

32. Mohandas J, Marshall JJ, Duggin GG, Horvath JS, Tiller DJ. Differential distribution of glutathione and glutathione-related enzymes in rabbit kidney. Possible implications in analgesic nephropathy. Biochemical pharmacology. 1984;33(11):1801-7.

33. Riu J, Maroto A, Rius FX. Nanosensors in environmental analysis. Talanta. 2006; 69(2): 288-301.

34. Hou J, Wang L, Wang C, Zhang S, Liu H, Li S, et al. Toxicity and mechanisms of action of titanium dioxide nanoparticles in living organisms. Journal of environmental sciences (China). 2019;75:40-53.

35. Bessa MJ, Costa C, Reinosa J, Pereira C, Fraga $\mathrm{S}$, Fernández J, et al. Moving into advanced nanomaterials. Toxicity of rutile $\mathrm{TiO}_{2}$ nanoparticles immobilized in nanokaolin nanocomposites on HepG2 cell line. Toxicology and applied pharmacology. 2017;316:114-22.

36. Karmakar A, Zhang Q, Zhang Y. Neurotoxicity of nanoscale materials. Journal of Food and Drug Analysis Journal of Food and Drug Analysis. 2014;22(1):147-60.

37. Liu Y, Xu Z, Li X. Cytotoxicity of titanium dioxide nanoparticles in rat neuroglia cells. Brain Injury Brain Injury. 2013;27(7-8):934-9.

38. Xu J, Shi H, Ruth M, Yu H, Lazar L, Zou B, et al. Acute Toxicity of Intravenously Administered Titanium Dioxide Nanoparticles in Mice. PLoS ONE PLoS ONE. 2013;8(8):e70618.

39. Federici G, Shaw B, Handy R. Toxicity of titanium dioxide nanoparticles to rainbow trout (Oncorhynchus mykiss): Gill injury, oxidative stress, and other physiological effects. Aquatic Toxicology Aquatic Toxicology. 2007;84(4):415-30.

40. Wang J, Liu Y, Jiao F, Lao F, Li W, Gu Y, et al. Time-dependent translocation and potential impairment on central nervous system by intranasally instilled $\mathrm{TiO}_{2}$ nanoparticles. TOX Toxicology. 2008;254 (1-2): 82-90.
41. Li Y, Li J, Yin J, Li W, Kang C, Huang Q, et al. Systematic Influence Induced by $3 \mathrm{~nm}$ Titanium Dioxide Following Intratracheal Instillation of Mice. J Nanosci Nanotech Journal of Nanoscience and Nanotechnology. 2010;10(12):8544-9.

42. Aijie C, Huimin L, Jia L, Lingling O, Limin W, Junrong $\mathrm{W}$, et al. Central neurotoxicity induced by the instillation of $\mathrm{ZnO}$ and $\mathrm{TiO}_{2}$ nanoparticles through the taste nerve pathway. Nanomedicine (London, England). 2017;12(20):2453-70.

43. Chen J, Dong X, Xin Y, Zhao M. Effects of titanium dioxide nano-particles on growth and some histological parameters of zebrafish (Danio rerio) after a long-term exposure. Aquat Toxicol Aquatic Toxicology. 2011;101(3-4):493-9.

44. Wang J, Chen C, Liu Y, Jiao F, Li W, Lao F, et al. Potential neurological lesion after nasal instillation of TiO 2 nanoparticles in the anatase and rutile crystal phases. TOXLET Toxicology Letters. 2008;183(1):72-80.

45. Song B, Liu J, Feng X, Wei L, Shao L. A review on potential neurotoxicity of titanium dioxide nanoparticles. Nanoscale Res Lett. 2015;10(1):1042.

46. Czajka M, Sawicki K, Popek S, Kruszewski M, Kapka-Skrzypczak L, Sikorska K, et al. Toxicity of titanium dioxide nanoparticles in central nervous system. Toxicol Vitro Toxicology in Vitro. 2015;29(5):1042-52.

47. Eng LF, Ghirnikar RS, Lee YL. Glial Fibrillary Acidic Protein: GFAP-Thirty-One Years (1969-2000). Neurochemical research. 2000;25(9):1439.

48. Shun-Fen T, Han-Yun H, Oi-Tong M. Prostaglandins and Cyclooxygenases in Glial Cells During Brain Inflammation. Current Drug Target -Inflammation \& Allergy. 2005;4(3):335-40.

49. Ze Y, Hu R, Wang X, Sang X, Ze X, Li B, et al. Neurotoxicity and gene-expressed profile in braininjured mice caused by exposure to titanium dioxide nanoparticles $\mathrm{TiO}<$ sub $>2</$ sub $>$ NP-Induced Brain Toxicity. J Biomed Mater Res Journal of Biomedical Materials Research Part A. 2014;102(2):470-8.

50. Clémence D, Jérôme $D$, Anne $C$, Monique C, Nathalie H-B, Emilie B, et al. Tissue biodistribution of intravenously administrated titanium dioxide nanoparticles revealed blood-brain barrier clearance and brain inflammation in rat. Particle and Fibre Toxicology. 2015;12:27.

51. Grissa I, Guezguez S, Ezzi L, Chakroun S, Sallem A, Kerkeni E, et al. The effect of titanium dioxide nanoparticles on neuroinflammation response in rat brain. ENVIRONMENTAL SCIENCE AND POLLUTION RESEARCH INTERNATIONAL. 2016;23(20):20205-13. 
52. Resendes AR, Majó N, Segalés J, Espadamala $\mathrm{J}$, Mateu E, Chianini F, et al. Apoptosis in normal lymphoid organs from healthy normal, conventional pigs at different ages detected by TUNEL and cleaved caspase-3 immunohistochemistry in paraffin-embedded tissues. Veterinary immunology and immunopathology. 2004;99(3-4):3-4.

53. Jakob S, Corazza N, Diamantis E, Kappeler A, Brunner T. Detection of apoptosis in vivo using antibodies against caspase-induced neo-epitopes. Methods Methods. 2008;44(3):255-61.

54. Long TC, Tajuba J, Sama P, Saleh N, Swartz $\mathrm{C}$, Parker $\mathrm{J}$, et al. Nanosize titanium dioxide stimulates reactive oxygen species in brain microglia and damages neurons in vitro. Environ Health Perspect. 2007;115(11):1631-7.

55. Ma L, Liu J, Li N, Wang J, Duan Y, Yan J, et al. Oxidative stress in the brain of mice caused by translocated nanoparticulate $\mathrm{TiO}_{2}$ delivered to the abdominal cavity. Biomaterials Biomaterials. 2010;31(1):99-105.

56. Rajakumar G, Rahuman AA, Roopan SM, Khanna VG, Elango G, Kamaraj C, et al. Fungus-mediated biosynthesis and characterization of $\mathrm{TiO}<\mathrm{sub}>2<1$ sub> nanoparticles and their activity against pathogenic bacteria. Spectrochimica acta Part A, Molecular and biomolecular spectroscopy. 2012;91:23-9.

57. Shrivastava R, Raza S, Yadav A, Kushwaha P, Flora SJS. Effects of sub-acute exposure to $\mathrm{TiO}_{2}, \mathrm{ZnO}$ and $\mathrm{A} 12 \mathrm{O} 3$ nanoparticles on oxidative stress and histological changes in mouse liver and brain. Drug and Chemical Toxicology. 2014;37(3):336-47.

58. Hu R, Zheng L, Gao G, Cui Y, Cheng Z, Cheng $\mathrm{J}$, et al. Molecular mechanism of hippocampal apoptosis of mice following exposure to titanium dioxide nanoparticles. J Hazard Mater Journal of Hazardous Materials. 2011;191(1-3):32-40.

59. Martín JF GE, Barredo JL. Conversion of b-carotene into astaxanthin: Two separate enzymes or a bifunctional hydroxylase-ketolase protein? 2008.

60. Orazizadeh M, Khorsandi L, Absalan F, Hashemitabar M, Daneshi E. Effect of betacarotene on titanium oxide nanoparticles-induced testicular toxicity in mice. J Assist Reprod Genet Journal of Assisted Reproduction and Genetics. 2014;31(5):561-8.

61. Peng HC, Chen JR, Chen YL, Yang SC, Yang SS. \&\#x03B2;-carotene exhibits antioxidant and antiapoptotic properties to prevent ethanolinduced cytotoxicity in isolated rat hepatocytes. Phytother Res Phytotherapy Research. 2010; 24 (SUPPL. 2): S183-S9.

62. Bestwick CS, Milne L. Effects of beta-carotene on antioxidant enzyme activity, intracellular reactive oxygen and membrane integrity within post confluent Caco-2 intestinal cells. Biochimica et biophysica acta. 2000;1474(1):47-55.

63. Yang SC, Huang CC, Chu JS, Chen JR. Effects of beta-carotene on cell viability and antioxidant status of hepatocytes from chronically ethanol-fed rats. The British journal of nutrition. 2004;92(2):209-15.

64. Soliman M, Attia H, Ismail T. PROTECTIVE EFFECT OF N-ACETYLCYSTIENE AGAINST TITANIUM DIOXIDE NAONPARTICLES MODULATED IMMUNE RESPONSE IN MALE ALBINO RATS. American journal of immunology. 2013;9:148-58.

65. Xue C, Liu W, Yang X, Xu H, Wu J. Chemoprotective effect of $\mathrm{N}$-acetylcysteine (NAC) on cellular oxidative damages and apoptosis induced by nano titanium dioxide under UVA irradiation. Toxicol Vitro Toxicology in Vitro. 2011;25(1):110-6. 
الملخص العربى

دور بيتا كاروتين ضد التأثير السمي لجسيمات نانو ثاني أكسيد التيتانيوم على قشرة

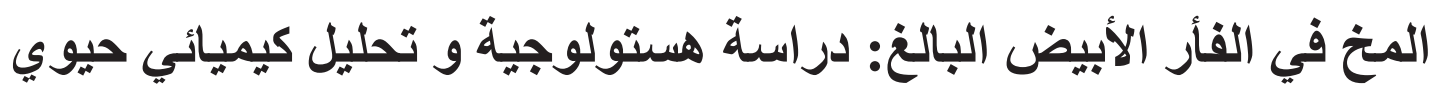

\author{
ريهام حلمي عبد الكريم، وآيات محمود الاموكي \\ قسم التشريح الآدمى والأجنة، كلية الطب، جامعة ولئمة الزقازيق
}

الهرف من البحث: تحقيق رؤية جديدة للتأثير السمي العصبي لجسيمات نانو ثاني أكسيد التيتانيوم من خلال فحص التغير ات المرضية والكيميائية الحيوية في القترة الدماغية للفئران البيضاء، وتقييم الدور الوقيائي الدئي المحتمل للكاروتين من هذه السمية. طريقة البحث: تم تقسيم •ـ من الفئران البيضاء اللى ه مجمو عات: ا ـ مجموعة الجرعة المنخفضة: تم اعطاء جسيمات نانو ثاني أكسيد التيتانيوم عن طريق الحقن داخل الصفاق ل. ملغم / كغ ، يوميًا لمدة ؟ ا يومًا.

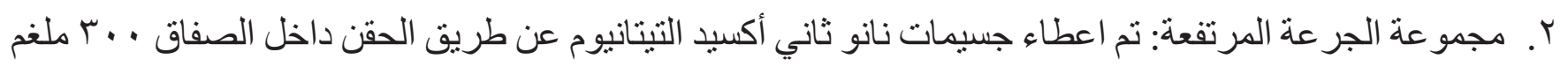

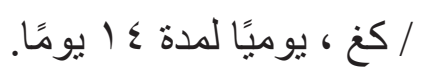

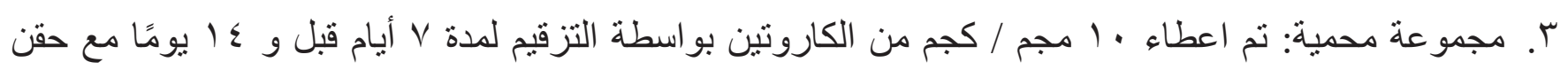

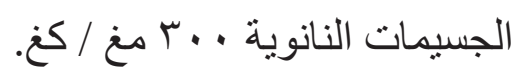

ع. ـ مجموعة المر اقبذة: تم اعطاء محلول ملحي عن طريق الحقن داخل الصفاق ب ملغم / كغم ، يوميًا لمدة ـ ا يومًا.

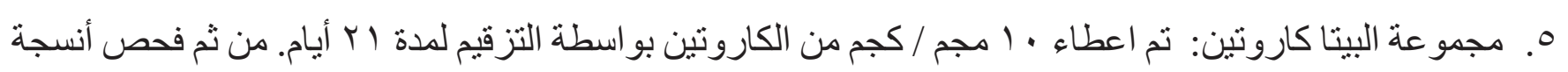

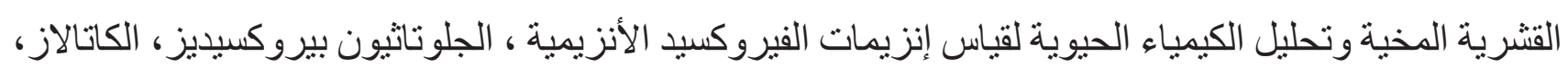

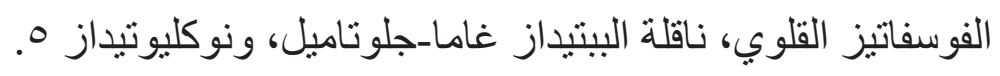
نتائج البحث: على عكس إعطاء جرعة منخفضة من جسيمات التيتانيوم، أدى إعطاء جرعة كبيرة من جسيمات

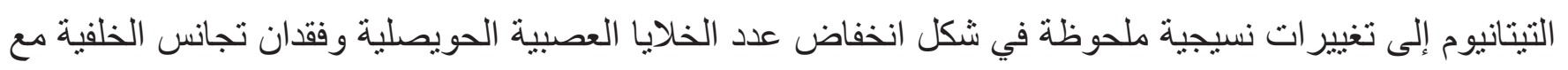
ظهور فر اغات وتغير ات مائية. و علاوة على ذلك ، زيادة في عدد الخلايا النجمية مع ظهور مساحة التسمم وزيادة في

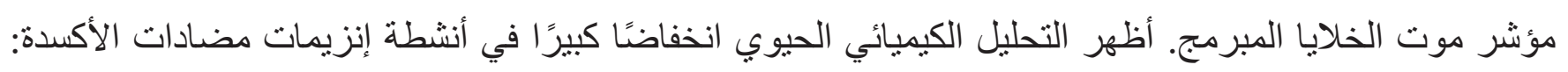
ديسموناز الفائق أكسي، والغلوتاثيون بيروكسيديز و الكاتالاز. بالإضافة إلى ذل ، انخفاض كبير في أنشطة الفوسفاتيز

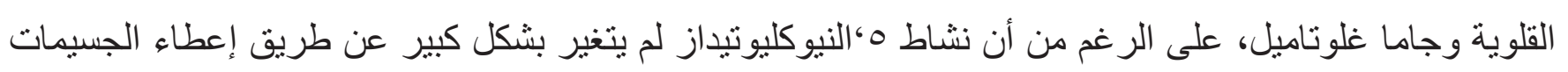
النانوية. هذه التغيير ات لم تظهر بشكل ملحوظ باستخدام بيتا كاروتين. الخلاصة من البحث: اعطاء البيتا كاروتين بعتبر بمثابة دو اء مفيد للحماية من السمية العصبية التي تسبيها الجسيمات 